Article

\title{
Phosphorus and Nitrogen Adsorption Capacities of Biochars Derived from Feedstocks at Different Pyrolysis Temperatures
}

\author{
Lei Zhou ${ }^{1,2}$, Defu Xu ${ }^{1,2,3,4, *}$, Yingxue Li ${ }^{4}$, Qianchen Pan ${ }^{2}$, Jiajun Wang ${ }^{1,2}$, Lihong Xue ${ }^{3}$ and \\ Alan Howard ${ }^{5, *}$ \\ 1 Collaborative Innovation Center of Atmospheric Environment and Equipment Technology, Nanjing 210044, \\ China \\ 2 School of Environmental Science and Engineering, Nanjing University of Information Science \& Technology, \\ Nanjing 210044, China \\ 3 Key Laboratory of Agro-Environment in Downstream of Yangze Plain, Ministry of Agriculture, \\ Nanjing 210014, China \\ 4 Jiangsu Key Laboratory of Atmospheric Environment Monitoring and Pollution Control, Nanjing 210044, \\ China \\ 5 Department of Geography and Environmental Science, University of Reading, Reading RG6 6AB, UK \\ * Correspondence: defuxu1@163.com (D.X.); a.howard@reading.ac.uk (A.H.); Tel.: +86-025-5869-5684 (D.X.); \\ +44-118-378-8763 (A.H.)
}

Received: 14 June 2019; Accepted: 20 July 2019; Published: 28 July 2019

\begin{abstract}
This study investigates the $\mathrm{P}$ and $\mathrm{NO}_{3}{ }^{-}$adsorption capacities of different biochars made from plant waste including rice straw (RSB), Phragmites communis (PCB), sawdust (SDB), and egg shell (ESB) exposed to a range of pyrolysis temperatures $\left(300,500\right.$ and $\left.700{ }^{\circ} \mathrm{C}\right)$. Results indicate that the effect of pyrolysis temperature on the physiochemical properties of biochar varied with feedstock material. Biochars derived from plant waste had limited adsorption or even released $\mathrm{P}$ and $\mathrm{NO}_{3}{ }^{-}$, but adsorption of $\mathrm{P}$ capacity could be improved by adjusting pyrolysis temperature. The maximum adsorption of $\mathrm{P}$ on RSB700, PCB300, and SDB300, produced at pyrolysis temperature of 700, 300 and $300{ }^{\circ} \mathrm{C}$, was $5.41,7.75$ and $3.86 \mathrm{mg} \mathrm{g}^{-1}$, respectively. $\mathrm{ESB}$ can absorb both $\mathrm{P}$ and $\mathrm{NO}_{3}{ }^{-}$, and its adsorption capacity increased with an increase in pyrolysis temperature. The maximum $\mathrm{NO}_{3}{ }^{-}$and $\mathrm{P}$ adsorption for ESB700 was 1.43 and $6.08 \mathrm{mg} \mathrm{g}^{-1}$, respectively. The less negative charge and higher surface area of ESB enabled higher $\mathrm{NO}_{3}{ }^{-}$and $\mathrm{P}$ adsorption capacity. The $\mathrm{P}$ adsorption process on RSB, $\mathrm{PCB}, \mathrm{SDB}$ and ESB, and the $\mathrm{NO}_{3}{ }^{-}$adsorption process on ESB were endothermic reactions. However, the $\mathrm{NO}_{3}{ }^{-}$adsorption process on RSB, $\mathrm{PCB}$ and SDB was exothermic. The study demonstrates that the use of egg shell biochar may be an effective way to remove, through adsorption, $\mathrm{P}$ and $\mathrm{NO}_{3}{ }^{-}$ from wastewater.
\end{abstract}

Keywords: biochar; pyrolysis temperature; nitrogen; phosphorus; adsorption capacity

\section{Introduction}

Discharges of phosphorus $(\mathrm{P})$ and nitrate $\left(\mathrm{NO}_{3}{ }^{-}\right)$into the natural environment from agricultural, industrial, and domestic wastewater have increased in many countries. The resulting nutrient enrichment and eutrophication of water-bodies has become a serious environmental concern around the world [1,2]. Under eutrophic conditions, rapid growth of organisms, especially algae, may be stimulated resulting in depletion of dissolved oxygen and deterioration of the aquatic environment [3]. In addition, human health could be affected by high levels of $\mathrm{NO}_{3}{ }^{-}$in water. For example, infant methemoglobinemia and several types of cancers could occur due to human uptake of excess 
$\mathrm{NO}_{3}{ }^{-}$[4]. Therefore, removing excess $\mathrm{P}$ and $\mathrm{NO}_{3}{ }^{-}$from wastewaters has important ecological and social implications.

Technologies used to remove $\mathrm{P}$ and $\mathrm{NO}_{3}{ }^{-}$from wastewaters are mainly divided into three categories: chemical, biological and physical methods [5]. Chemical treatments may produce additional pollutants, such as sludge, due to the precipitation of $\mathrm{P}$ [6]. Biological treatments may increase the cost of wastewater treatment because of the requirement for aeration or other pre-treatments [7]. Physical treatments include many methods, such as electrodialysis, reverse osmosis and adsorption. Compared to electrodialysis and reverse osmosis, adsorption is a widely used and promising method of purifying wastewater in situ because it is relatively low-cost and efficient and is less likely to generate secondary pollution $[8,9]$. Therefore, investigation of economical and effective adsorbents to remove $\mathrm{P}$ and $\mathrm{NO}_{3}{ }^{-}$ from wastewaters has much potential value.

Large amounts of bio-wastes, such as straw and manure, are produced from agriculture and industrial activities [10]. For example, the annual production of agricultural waste is approximately 0.7 billion tonnes in China, of which $70 \%$ is rice straw, wheat straw, and corn stalk [11]. Egg shell is a waste from daily life, and its annual production is about 3.7 million tonnes in China [12]. Large quantities of bio-waste have resulted in many environmental problems, such as water pollution due to its leachate, and air pollution due to its burning. Therefore, it is very important to find sustainable solutions to solve bio-waste issues, and biochar production offers a viable approach. As well as possibly aiding the removal of $\mathrm{P}$ and $\mathrm{NO}_{3}{ }^{-}$from wastewaters, biochars may be applied to soil to serve as an amendment to increase plant growth, and reduce bioavailability, phytotoxicity, and uptake of heavy metals in contaminated soil [13]. Biochars that are used as adsorption agents in wastewater, could, therefore, be subsequently re-used as a soil amendment.

There have, however, been inconsistent results on $\mathrm{NO}_{3}{ }^{-}$and $\mathrm{P}$ adsorption by biochars. Yao et al., for example, found that $\mathrm{NO}_{3}{ }^{-}$leaching was reduced by $14.0-34.0 \%$ when a biochar produced from Brazilian pepper wood and peanut hull at $600{ }^{\circ} \mathrm{C}$ was added to soil [14]. However, Hale et al. [15] found that cacao shell and corn cob biochar did not adsorb $\mathrm{NO}_{3}{ }^{-}$and, in fact, sometimes increased the release of $\mathrm{NO}_{3}{ }^{-}$into the environment. Jung and Hong [16], for example, found an adsorption of $8.3 \mathrm{mg} \mathrm{g}^{-1}$ of phosphate in a biochar from seaweed pyrolysis at $600{ }^{\circ} \mathrm{C}$. Michalekova-Richveisova et al. [17] demonstrated that the maximum phosphate adsorption capacity was $0.036 \mathrm{mg} \mathrm{g}^{-1}, 0.132 \mathrm{mg} \mathrm{g}^{-1}$ and $0.296 \mathrm{mg} \mathrm{g}^{-1}$, respectively for a corn cobs biochar, garden wood waste biochar and wood chips biochar. However, Novaisa et al. [18] demonstrated that biochars would not be able to adsorb significant amounts of phosphate due to the large amount of phenolic and carboxylic groups and a high proportion of fulvic and humic acids. Similarly, some biochars, such as wild fire biochar, Jarrah biochar, greenwaste biochar, sugarcane bagasse biochar and blady grass biochar, do not have the capacity to adsorb phosphate and can actually release P into solution [19]. Therefore, research to identify the physiochemical properties of biochars most suitable for removal of $\mathrm{P}$ and $\mathrm{N}$ from wastewater remains very important.

Adsorption of nitrogen $(\mathrm{N})$ and $\mathrm{P}$ may be influenced by many factors, including its $\mathrm{CEC}$, acidic functional groups, surface oxygen-containing functional groups [20], surface charges and available anion exchange sites [21]. In addition, Chintala et al. [22] found that $\mathrm{P}$ adsorption by biochars was significantly affected by initial $\mathrm{P}$ concentration in the solution. Therefore, $\mathrm{P}$ and $\mathrm{NO}_{3}{ }^{-}$adsorption is related to the biochar's physiochemical properties, and the initial $\mathrm{P}$ and $\mathrm{NO}_{3}{ }^{-}$concentration. However, there is little information on how biochars derived from plant waste and egg shell affect $\mathrm{P}$ and $\mathrm{NO}_{3}{ }^{-}$ adsorption at varying pyrolysis temperatures. The objectives of this study therefore include: (1) to examine capacity of $\mathrm{P}$ and $\mathrm{NO}_{3}{ }^{-}$adsorption of different biochars produced under different pyrolysis temperatures; (2) to investigate the adsorption process of $\mathrm{P}$ and $\mathrm{NO}_{3}{ }^{-}$by the biochars. The results will offer a theoretical and practical foundation for removal of $\mathrm{P}_{\text {and }} \mathrm{NO}_{3}{ }^{-}$from eutrophic or wastewaters using biochars. 


\section{Materials and Methods}

\subsection{Materials}

Four types of materials, i.e., rice straw, Phragmites communis, sawdust and egg shell were obtained from Nanjing University of Information Science and Technology, Nanjing, China. The materials were rinsed with water and air-dried, then ground and sieved to $<2.0 \mathrm{~mm}$ particles using a stainless grinding machine. The powdered biomass was tightly placed in a ceramic pot, and then pyrolyzed in a muffle furnace. The pyrolysis was programmed to drive temperature to $300{ }^{\circ} \mathrm{C}, 500{ }^{\circ} \mathrm{C}$ and $700{ }^{\circ} \mathrm{C}$ at a rate of $5^{\circ} \mathrm{C} \mathrm{min}^{-1}$, respectively, and held at the peak temperature for $2 \mathrm{~h}$ before being cooled to room temperature. The biochars produced from rice straw, Phragmites communis, sawdust and egg shell under $300{ }^{\circ} \mathrm{C}, 500{ }^{\circ} \mathrm{C}$ and $700{ }^{\circ} \mathrm{C}$ were referred to as RSB300, RSB500, RSB700, PCB300, PCB500, PCB700, SDB300, SDB500, SDB700, ESB300, ESB500 and ESB700, respectively. All biochar samples were ground to pass through a $0.5 \mathrm{~mm}$ sieve prior to use.

\subsection{Adsorption Kinetics Experiments}

The stock solutions of $\mathrm{P}$ and $\mathrm{NO}_{3}{ }^{-}-\mathrm{N}$ were prepared using $\mathrm{KH}_{2} \mathrm{PO}_{4}$ and $\mathrm{KNO}_{3}$, respectively. Sorption kinetics were evaluated at room temperature $\left(30^{\circ} \mathrm{C}\right)$ and the initial $\mathrm{pH}$ for each sorption solution was adjusted to 7 prior to the experiments. The biochar $(0.2 \mathrm{~g})$ was added into $20 \mathrm{~mL}$ solutions containing $20 \mathrm{mg} \mathrm{P}$ or $\mathrm{NO}_{3}{ }^{-}-\mathrm{N} \mathrm{L}^{-1}$. Subsamples were taken after $30 \mathrm{~min}, 60 \mathrm{~min}, 180 \mathrm{~min}$, $300 \mathrm{~min}, 420 \mathrm{~min}, 780 \mathrm{~min}, 1080 \mathrm{~min}$ and $1440 \mathrm{~min}$, and shaken at $180 \mathrm{rpm}$ in a mechanical shaker. The subsamples were then filtered with a syringe filter. The concentrations of $\mathrm{NO}_{3}{ }^{-}-\mathrm{N}^{-}$ and $\mathrm{P}$ in the filtrate were determined by ultraviolet spectrophotometry and ammonium molybdate spectrophotometry, respectively.

The amount of $\mathrm{P}$ and $\mathrm{NO}_{3}{ }^{-}$adsorbed by the biochars was calculated by the following equation (Equation (1)).

$$
q_{t}=\frac{\left(C_{0}-C_{t}\right) \times V}{W}
$$

where $q_{t}\left(\mathrm{mg} \mathrm{g}^{-1}\right)$ is the amount of $\mathrm{P}$ and $\mathrm{NO}_{3}{ }^{-}$adsorbed by the biochars; $C_{0}$ and $C_{t}\left(\mathrm{mg} \mathrm{L}^{-1}\right)$ are the initial and time concentrations of the pollutants, respectively; $V(\mathrm{~L})$ is the volume of adsorption solution; and $W(\mathrm{~g})$ is the mass of biochar.

The experimental results were fitted using three typical kinetic models (Pseduo-first-order Equation (2), Pseduo-second-order Equation (3) and Intraparticle diffusion Equation (4).

$$
\begin{gathered}
\ln \left(q_{e}-q_{t}\right)=\ln q_{e}-k_{1} t \\
\frac{t}{q_{t}}=\frac{1}{k_{2} q_{e}^{2}}+\frac{t}{q_{e}}=\frac{1}{h}+\frac{t}{q_{e}} \\
q_{t}=k_{3} t^{0.5}+C
\end{gathered}
$$

where $q_{e}$ and $q_{t}\left(\mathrm{mg} \mathrm{g}^{-1}\right)$ are the amounts of $\mathrm{P}$ and $\mathrm{NO}_{3}{ }^{-}$adsorbed by the biochars at the equilibrium time and at time $t$, respectively; $k_{1}\left(\mathrm{~h}^{-1}\right), k_{2}\left(\mathrm{~g} \mathrm{mg}^{-1} \mathrm{~h}^{-1}\right)$, and $k_{3}\left(\mathrm{mg} \mathrm{g}^{-1} \mathrm{~h}^{-0.5}\right)$ are the rate constants of the corresponding model; and $C\left(\mathrm{mg} \mathrm{g}^{-1}\right)$ is a constant.

\subsection{Adsorption Isotherm Experiment}

Sorption isotherms of $\mathrm{P}$ or $\mathrm{NO}_{3}{ }^{-}-\mathrm{N}$ were determined using batch experiments in the centrifugal tube under the same conditions as above, and the concentration of $\mathrm{P}$ varied from 0 to $320 \mathrm{mg} \mathrm{L}^{-1}(0,5$, $10,20,40,80,160$ and $\left.320 \mathrm{mg} \mathrm{L}^{-1}\right)$ or concentration of $\mathrm{NO}_{3}{ }^{-}-\mathrm{N}$ varied from 0 to $320 \mathrm{mg} \mathrm{L}^{-1}(0,5,10$, 20, 40, 80, 160 and $320 \mathrm{mg} \mathrm{L}^{-1}$ ). After being shaken for $24 \mathrm{~h}$, the final suspensions were centrifuged, 
filtered, and the supernatant solution was separated for analysis of $\mathrm{P}_{\text {or }} \mathrm{NO}_{3}{ }^{-}$. The concentration of $\mathrm{P}$ or $\mathrm{NO}_{3}{ }^{-}$was calculated Equation (5).

$$
q_{e}=\frac{\left(C_{0}-C_{e}\right) \times V}{W}
$$

where $q_{e}$ is the equilibrium $\mathrm{P}$ or $\mathrm{NO}_{3}{ }^{-}$concentration in $\mathrm{mg} \mathrm{g}^{-1} ; V$ is the volume of $\mathrm{P}$ or $\mathrm{NO}_{3}{ }^{-}$aqueous solution in $\mathrm{L} ; W$ is the adsorbent mass in $\mathrm{g}$; $\mathrm{C}_{0}$ is the initial $\mathrm{P}_{\text {or }} \mathrm{NO}_{3}{ }^{-}$concentration in $\mathrm{mg} \mathrm{L}^{-1}$; and $C_{e}$ is the aqueous $\mathrm{P}_{\text {or }} \mathrm{NO}_{3}{ }^{-}$concentration at equilibrium in $\mathrm{mg} \mathrm{L}^{-1}$.

Sorption isotherms were fitted to the Langmuir (Equation (6) and Freundlich (Equation (7)) equations to quantify the adsorption capacity of different biochars.

$$
\begin{gathered}
q_{e}=\frac{q_{\max } K_{L} C_{e}}{1+K_{L} C_{e}} \\
q_{e}=K_{F} C_{e}^{\frac{1}{n}}
\end{gathered}
$$

where $q_{e}\left(\mathrm{mg} \mathrm{g}^{-1}\right)$ is the adsorption capacity; $C_{e}\left(\mathrm{mg} \mathrm{L}^{-1}\right)$ is the equilibrium concentration after the adsorption or desorption; $1 / \mathrm{n}$ is the intensity of adsorption or affinity; $K_{F}\left(\mathrm{mg} \mathrm{g}^{-1}\right)$ is the Freundlich adsorption constant; $q_{\max }\left(\mathrm{mg} \mathrm{g}^{-1}\right)$ is the maximum sorption capacity; $K_{L}\left(\mathrm{~L} \mathrm{mg}^{-1}\right)$ is a Langmuir constant.

\subsection{Adsorption Thermodynamics}

Sorption data of RSB700, PCB300, SDB300, and ESB700 using initial $\mathrm{P}$ or $\mathrm{NO}_{3}{ }^{-}$concentration $\left(20,40,80,160\right.$ and $\left.320 \mathrm{mg} \mathrm{L}^{-1}\right)$ at a temperature range of 20,30 and $40^{\circ} \mathrm{C}$ were collected after $24 \mathrm{~h}$ equilibration time. Three parameters (Gibb's free energy change $\left(\Delta G^{0}\right)$, enthalpy change $\left(\Delta H^{0}\right)$ and entropy change $\left(\Delta S^{0}\right)$ ) were calculated using the following equations.

The thermodynamic equilibrium constant $K c$ was defined as (Equation (8)):

$$
K c=\frac{C_{0}-C_{e}}{C e}
$$

where $C_{0}$ and $C_{e}\left(\mathrm{mg} \mathrm{L}^{-1}\right)$ are the initial and equilibrium concentration of $\mathrm{P}$ or $\mathrm{NO}_{3}{ }^{-}$solution.

$\Delta G^{0}$ was calculated by the following equation (Equation (9)):

$$
\Delta G^{0}=-R T \operatorname{Ln} K c
$$

where, $T$ is temperature in $\mathrm{K}, R$ the ideal gas constant $=8.314 \mathrm{~J} \mathrm{~mol}^{-1} \mathrm{~K}^{-1}$.

$\Delta H^{0}$ and $\Delta S^{0}$ was calculated by the following equation (Equation (10)).

$$
\text { Ln Kc }=-\frac{\Delta G^{0}}{R T}=-\frac{\Delta H^{0}}{R T}+\frac{\Delta S^{0}}{R}
$$

Thus, from the linear plot of $\ln$ Kc versus $1 / \mathrm{T}$, the enthalpy $\left(\Delta H^{0}\right)$ and entropy $\left(\Delta S^{0}\right)$ values were calculated from the slope $\left(\Delta H^{0} / \mathrm{RT}\right)$ and intercept $\left(\Delta S^{0} / \mathrm{R}\right)$, respectively.

\subsection{Analysis Method}

The $\mathrm{pH}$ of biochars was measured by adding the biochars to deionized water at a mass/water ratio of 1:20 (PHS-3C). Each sample was analyzed in duplicate. The specific surface area and porosity properties of the biochars were measured by $\mathrm{N}_{2}$ adsorption isotherms at $77 \mathrm{~K}$ with the Brunauer-Emmett-Teller (BET) method and by $\mathrm{CO}_{2}$ isotherms at $273 \mathrm{~K}$ using a Quadrasorb Si-MP surface area analyzer. Zeta-potential measurements were performed at $\mathrm{pH} 7$ with a potential analyzer (Zetasizer Nano ZS90, Malvern, UK). 


\subsection{Statistical Analysis}

The average was calculated from three replicates of each experimental treatment using Origin Pro 8.0, and the results were indicated as mean \pm standard deviation. The kinetics and sorption isotherms were fitted using Origin Pro 8.0, and $\mathrm{R}^{2}$ values were used to compare the performance of different models. Statistical analysis was performed using SPSS 12.0. A one-way analysis of variance (ANOVA) was conducted for biochar characteristics. The tukey test was performed to detect the statistical significance of differences $(p<0.05)$ among means of treatments.

\section{Results and Discussion}

\subsection{Characteristics of Biochar}

According to Table 1, total volume, specific surface area and $\mathrm{pH}$ of RSB, PCB, SDB and ESB increased with pyrolysis temperatures, and the parameters were significantly higher at $700{ }^{\circ} \mathrm{C}$ than at $300^{\circ} \mathrm{C}(p<0.05)$.

Table 1. Textural properties of different biochars.

\begin{tabular}{ccccc}
\hline Sample & $\begin{array}{c}\text { Total Volume } \\
\left(\mathbf{c m}^{\mathbf{3}} \mathbf{g}^{-\mathbf{1}} \mathbf{)}\right.\end{array}$ & $\begin{array}{c}\text { Specific Surface } \\
\text { Area }\left(\mathbf{m}^{\mathbf{2}} \mathbf{g}^{\mathbf{- 1}} \mathbf{~}\right.\end{array}$ & $\mathbf{p H}$ & $\begin{array}{c}\text { Zeta Potential } \\
(\mathbf{m V})\end{array}$ \\
\hline RSB300 & $0.022 \pm 0.003^{\mathrm{a}}$ & $5.9 \pm 0.6^{\mathrm{a}}$ & $6.61 \pm 0.05^{\mathrm{a}}$ & $-30.50 \pm 0.70^{\mathrm{a}}$ \\
RSB500 & $0.072 \pm 0.008^{\mathrm{b}}$ & $34.0 \pm 3.6^{\mathrm{b}}$ & $9.28 \pm 0.07^{\mathrm{b}}$ & $-41.90 \pm 1.05^{\mathrm{b}}$ \\
RSB700 & $0.189 \pm 0.002^{\mathrm{c}}$ & $122.6 \pm 14.3^{\mathrm{c}}$ & $10.06 \pm 0.1^{\mathrm{c}}$ & $-19.35 \pm 1.92^{\mathrm{c}}$ \\
PCB300 & $0.008 \pm 0.0009^{\mathrm{a}}$ & $3.5 \pm 0.4^{\mathrm{a}}$ & $6.43 \pm 0.03^{\mathrm{a}}$ & $-39.30 \pm 0.76^{\mathrm{a}}$ \\
PCB500 & $0.106 \pm 0.002^{\mathrm{b}}$ & $131.5 \pm 14.3^{\mathrm{b}}$ & $6.82 \pm 0.02^{\mathrm{b}}$ & $-30.33 \pm 2.01^{\mathrm{b}}$ \\
PCB700 & $0.415 \pm 0.05^{\mathrm{c}}$ & $441.7 \pm 45.6^{\mathrm{c}}$ & $9.42 \pm 0.04^{\mathrm{c}}$ & $-23.41 \pm 0.70^{\mathrm{c}}$ \\
SDB300 & $0.006 \pm 0.0007^{\mathrm{a}}$ & $2.9 \pm 0.4^{\mathrm{a}}$ & $4.55 \pm 0.14^{\mathrm{a}}$ & $-25.63 \pm 0.54^{\mathrm{a}}$ \\
SDB500 & $0.233 \pm 0.03^{\mathrm{b}}$ & $378.7 \pm 39.6^{\mathrm{b}}$ & $6.03 \pm 0.02^{\mathrm{b}}$ & $-39.90 \pm 1.20^{\mathrm{b}}$ \\
SDB700 & $0.278 \pm 0.04^{\mathrm{b}}$ & $594.9 \pm 60.3^{\mathrm{c}}$ & $7.88 \pm 0.08^{\mathrm{c}}$ & $-16.60 \pm 0.29^{\mathrm{c}}$ \\
ESB300 & $0.004 \pm 0.0005^{\mathrm{a}}$ & $2.0 \pm 0.2^{\mathrm{a}}$ & $7.89 \pm 0.04^{\mathrm{a}}$ & $-9.99 \pm 0.92^{\mathrm{a}}$ \\
ESB500 & $0.006 \pm 0.0007^{\mathrm{ab}}$ & $3.7 \pm 0.4^{\mathrm{ab}}$ & $8.02 \pm 0.11^{\mathrm{a}}$ & $-4.94 \pm 1.63^{\mathrm{b}}$ \\
ESB700 & $0.009 \pm 0.0008^{\mathrm{b}}$ & $5.3 \pm 0.5^{\mathrm{b}}$ & $9.46 \pm 0.07^{\mathrm{b}}$ & $-2.99 \pm 1.37^{\mathrm{b}}$ \\
\hline
\end{tabular}

Data are means \pm SD of $n=3$. Different letters in the same column indicate significant differences in different pyrolysis temperature for each biochar $(p<0.05)$.

Zeta potential of PCB and ESB increased with pyrolysis temperatures (Table 1). The zeta potential significantly decreased for RSB and SDB produced from pyrolysis at $500{ }^{\circ} \mathrm{C}$ than at $300{ }^{\circ} \mathrm{C}(p<0.05)$. However, zeta potential significantly increased for RSB and SDB produced from pyrolysis at $700^{\circ} \mathrm{C}$ than at $300{ }^{\circ} \mathrm{C}$ or $500{ }^{\circ} \mathrm{C}(p<0.05)$. Results showed that the response of zeta potential of biochars on pyrolysis temperature varied with biochar type.

The SEM images of the studied biochars are shown in Figure 1, the more and uniform hollow channels for each biochar occurred with increasing pyrolysis temperature. Compared to RSB, PCB and SDB biochar, ESB biochar had less small pore size with relatively lower porosity (Figure 1).

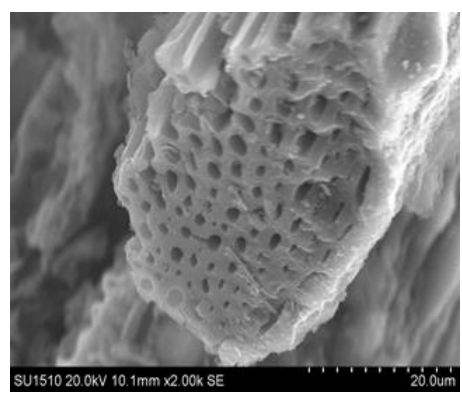

(a)

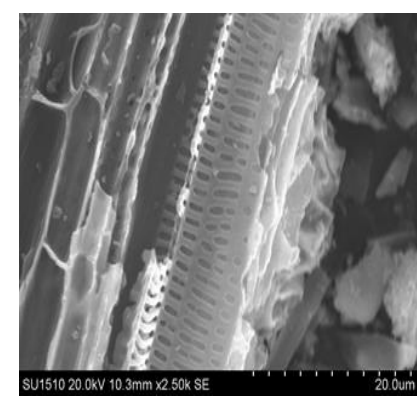

(b)

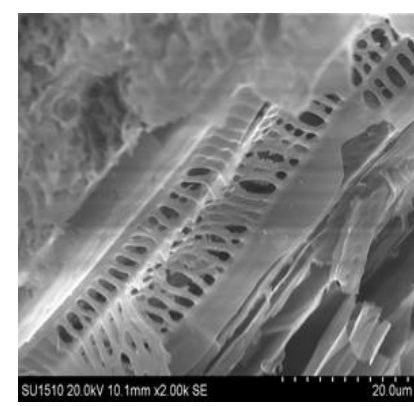

(c)

Figure 1. Cont. 


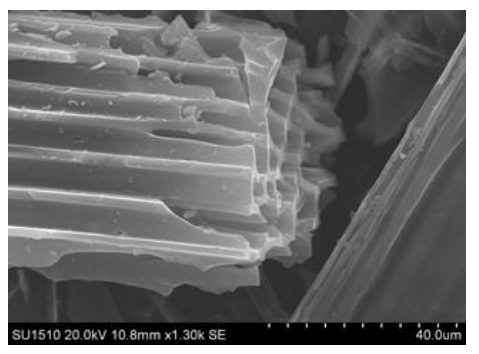

(d)

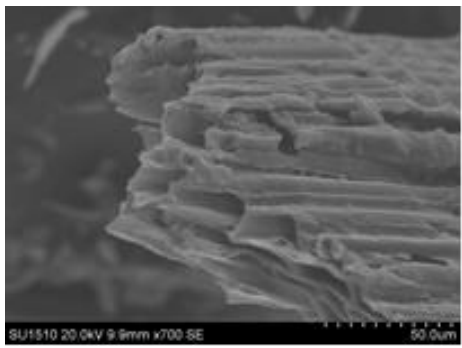

(g)

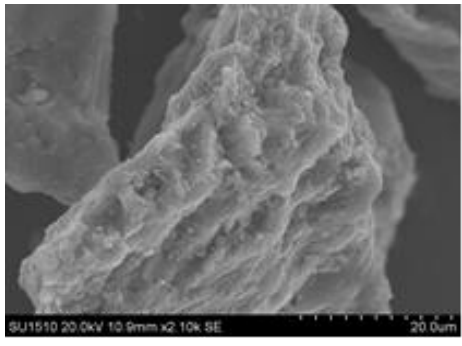

(j)

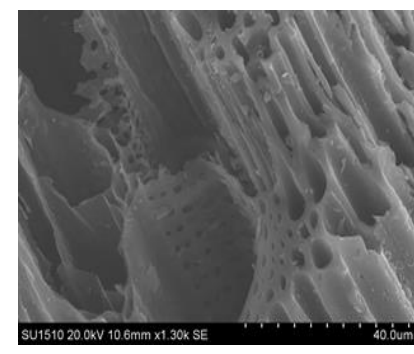

(e)

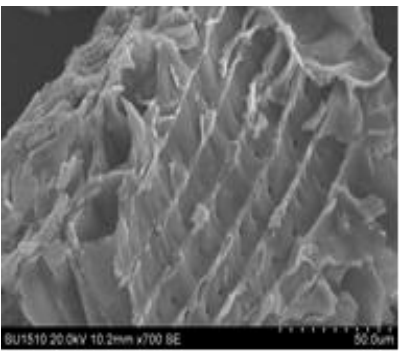

(h)

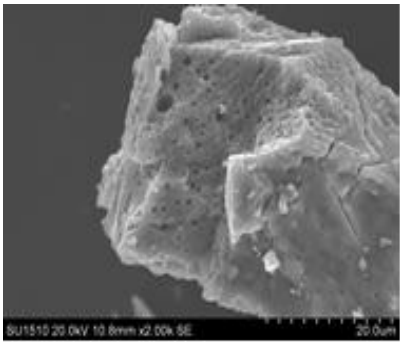

(k)

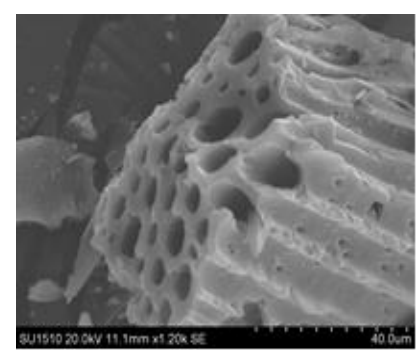

(f)

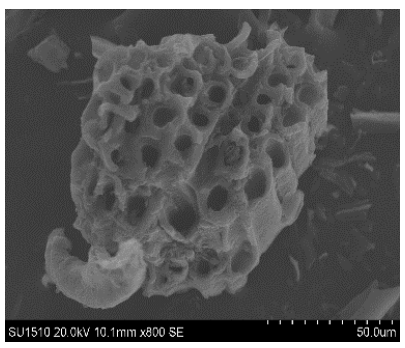

(i)

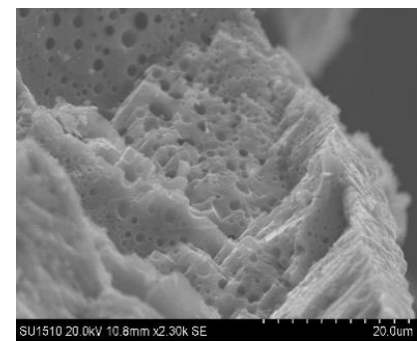

(1)

Figure 1. Scanning electron microscope (SEM) photos of RSB300 (a), RSB500 (b), RSB700 (c), PCB300 (d), PCB500 (e), PCB700 (f), SDB300 (g), SDB500 (h), SDB700 (i), ESB300 (j), ESB 500 (k) and ESB 700 (1), respectively.

\subsection{Sorption Kinetics of Biochar}

Adsorption or desorption of $\mathrm{P}$ on the biochars is shown in Figure 2. Release of P occurred in RSB300 and RSB500, PCB500 and PCB700, and SDB500 and SDB700 (Figure 2a-c), respectively. Similarly, PCB300 and SDB300 presented lower P adsorption capacity (Figure 2b,c): Novais et al. [23] showed that some biochars have very low or zero P adsorption, due to its behavior as "great anion", which prevents the adsorption of anions such as phosphates. Schneider and Haderlein [24] demonstrated that the dissolved organic matter released from the biochar pyrolysis at $200{ }^{\circ} \mathrm{C}$ when placed into the $\mathrm{P}$ solution competed for sorption sites and inhibited $\mathrm{P}$ sorption. However, our results show that $\mathrm{P}$ was adsorbed by ESB300, ESB500 and ESB700 (Figure 2d), P adsorption capacity is therefore dependent on biochar type and the rate of adsorption is affected by pyrolysis temperature. 


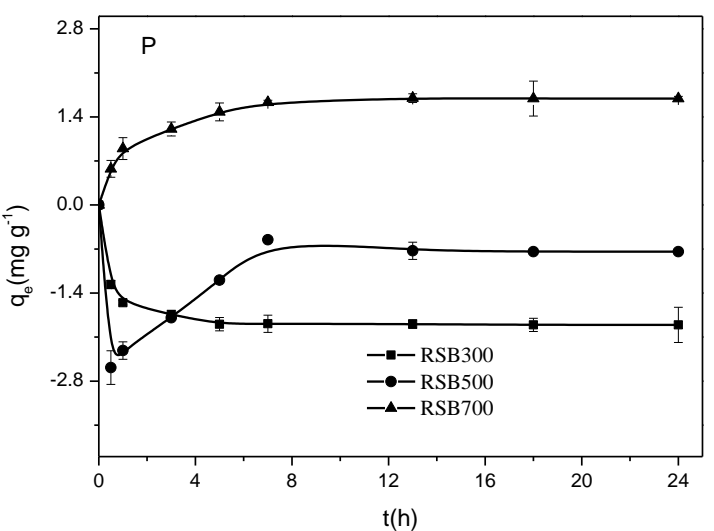

(a)

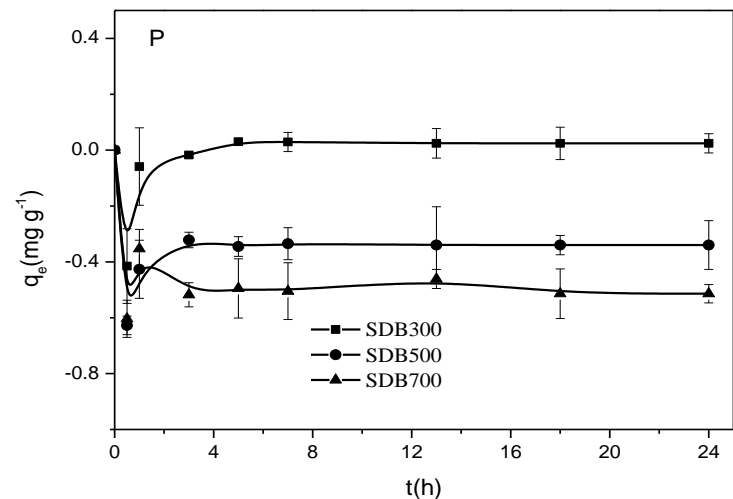

(c)

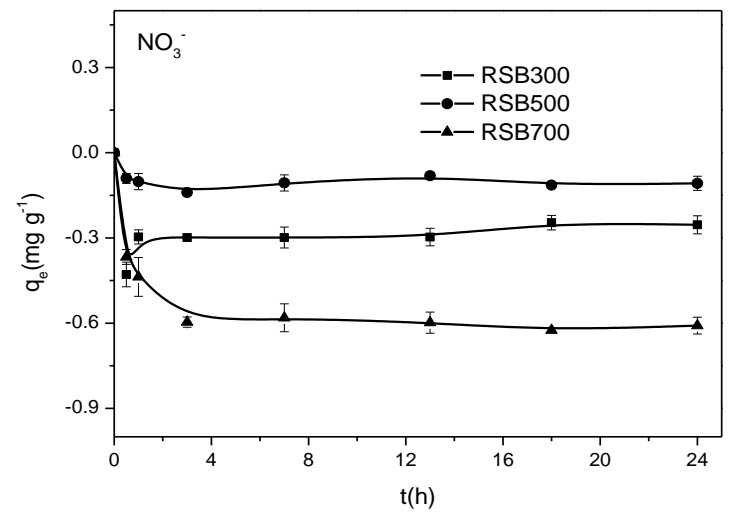

(e)

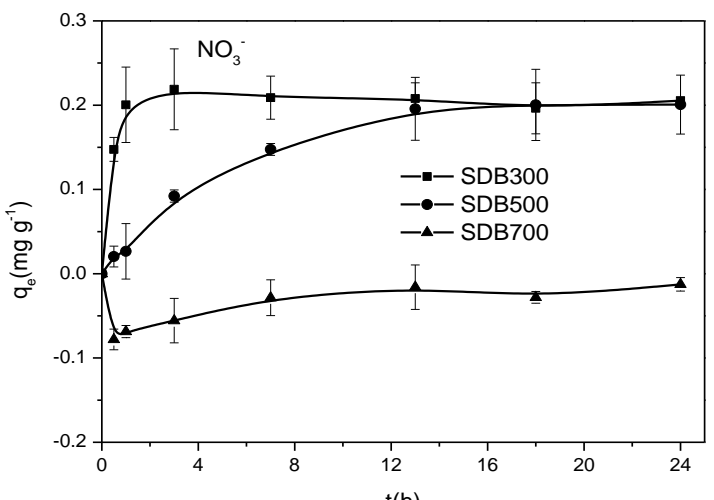

(g)

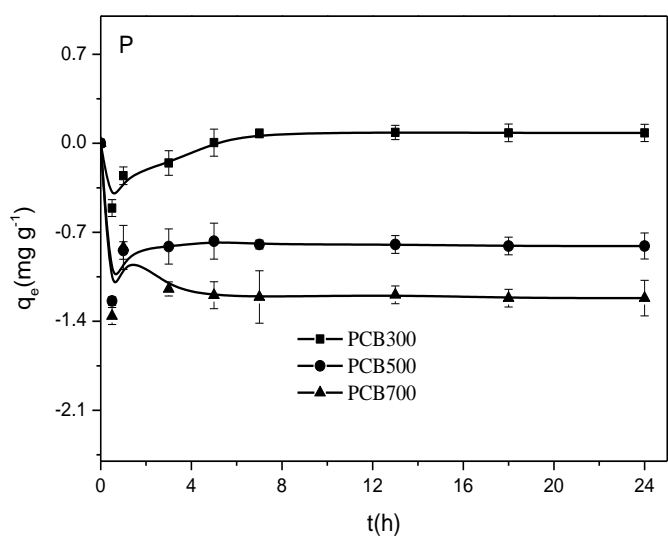

(b)

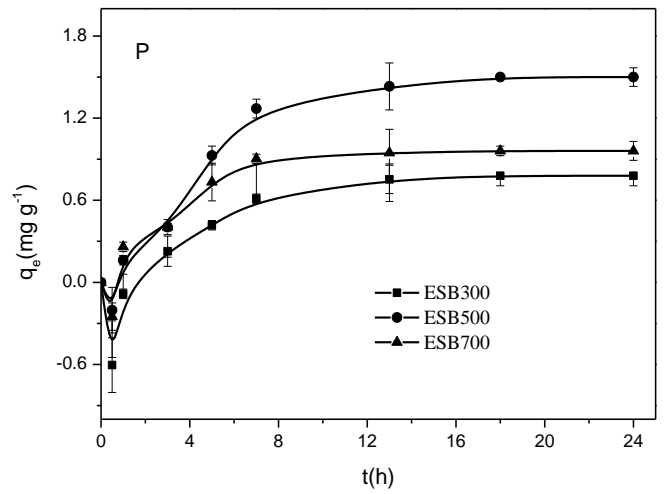

(d)

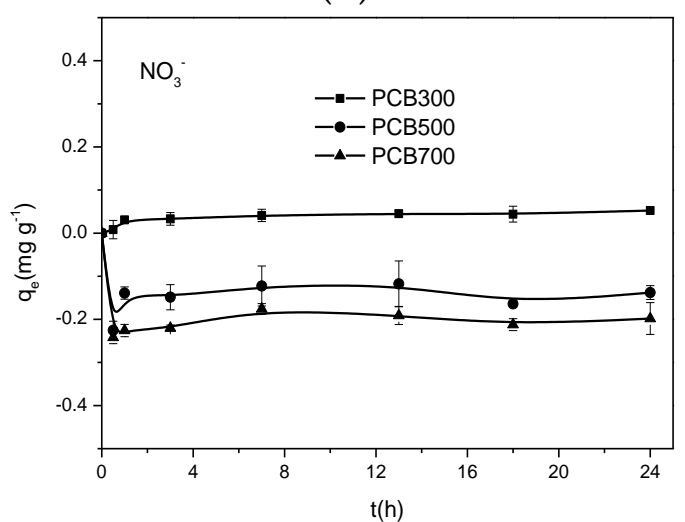

(f)

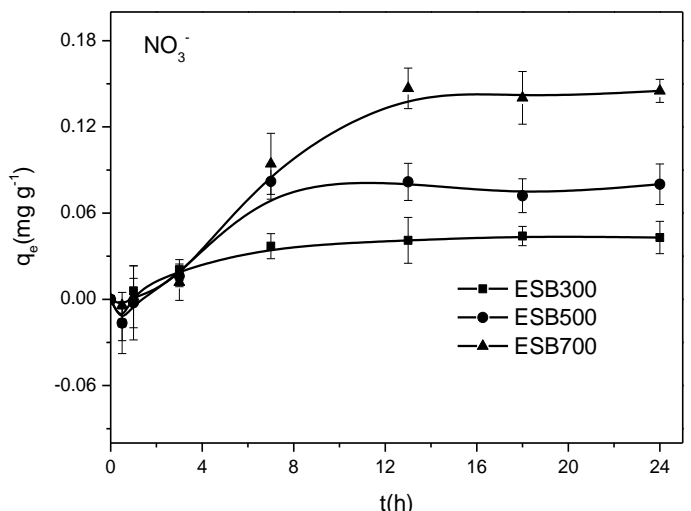

(h)

Figure 2. Adsorption kinetics of $\mathrm{P}$ and $\mathrm{NO}_{3}{ }^{-}$on RSB (a), PCB (b), SDB (c), ESB (d), RSB (e), PCB (f), $\operatorname{SDB}(\mathbf{g})$, and $\operatorname{ESB}(\mathbf{h})$, respectively. Data are means $\pm \operatorname{SD}$ of $n=3$. 
Release of $\mathrm{NO}_{3}{ }^{-}$occurred in RSB, PCB500, PCB700 and SDB700 (Figure 2e-g), respectively. However, adsorption of $\mathrm{NO}_{3}{ }^{-}$by ESB increased with time, and increased with pyrolysis temperature (Figure 2h). Therefore, ESB could adsorb both $\mathrm{P}$ and $\mathrm{NO}_{3}{ }^{-}$. As shown in Figure $2 \mathrm{~d}$,h, when the initial $\mathrm{P}$ and $\mathrm{NO}_{3}{ }^{-}$concentration was $20 \mathrm{mg} / \mathrm{L}$, rapid adsorption on ESB was observed in the first $8 \mathrm{~h}$, which suggested that $\mathrm{P}$ and $\mathrm{NO}_{3}{ }^{-}$in solution was impelled to adhere to the surface of biochar.

To investigate adsorption mechanisms of $\mathrm{P}_{\text {and }} \mathrm{NO}_{3}{ }^{-}$, the sorption data were fitted with kinetic models, including the pseudo-first-order, pseudo-second-order and intra-particle diffusion model. According to Table 2, the pseudo-second-order kinetic model for adsorption P on RSB700, PCB300 and SDB300 showed the best fit to the experimental data with the highest $\mathrm{R}^{2}$ in a range of $0.994-0.999$. These results are similar to those of Elsa et al. [25], who demonstrated that the pseudo-second-order kinetic model fits the experimental data better than the pseudo-first-order kinetic model for $\mathrm{P}$ adsorption. However, the pseudo-first-order kinetic model for ESB showed the best fit to the experimental data with the highest $R^{2}$ in a range of $0.984-0.995$ (Table 2). In this study, the intra-particle diffusion model didn't fit the data well with low $\mathrm{R}^{2}$ in a range of $0.601-0.893$ (Table 2), indicating that intrapore diffusion does not dominate the adsorption process of $\mathrm{P}$ on the biochars.

Table 2. Parameters of $\mathrm{P}$ adsorption kinetics of different biochars.

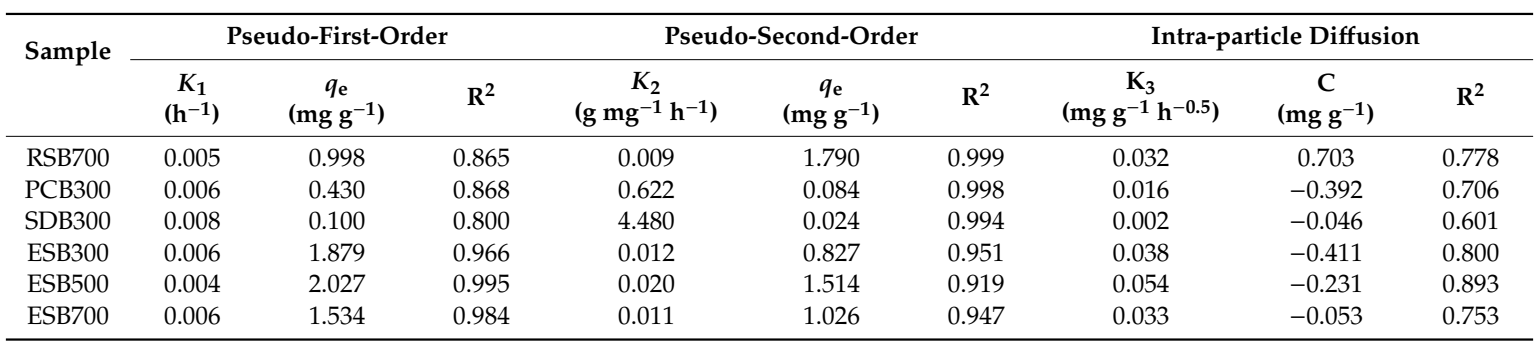

According to Table 3, the pseudo-second-order kinetic model for $\mathrm{NO}_{3}{ }^{-}$adsorption on PCB300, SDB300 and SDB500 showed the best fit to the experimental data with the highest $\mathrm{R}^{2}$ in a range of 0.974-0.992. This suggests that $\mathrm{NO}_{3}{ }^{-}$adsorption process is mainly chemical adsorption. However, the pseudo-first-order kinetic model for $\mathrm{NO}_{3}{ }^{-}$adsorption on ESB showed the best fit to the experimental data with the highest $R^{2}$ in a range of $0.906-0.989$. The results suggest that the intra-particle diffusion model didn't fit the data well with low $\mathrm{R}^{2}$ in a range of $0.784-0.914$ (Table 3). The pseudo-first-order model is widely used to describe reversible physical adsorption between the adsorbent and the adsorbate [26]. The pseudo-second-order model indicated that the adsorption of $\mathrm{P}$ onto calcium-flour biochar was a chemisorptions-dominated process [27]. Therefore, in this study, the pseudo-second-order model could be used to predict the kinetic process for $\mathrm{P}$ and $\mathrm{NO}_{3}{ }^{-}$sorption on $\mathrm{PCB}$ and SDB, which was a chemisorptions-dominated process. However, the pseudo-first-order model could be suitable to predict the kinetic process for $\mathrm{P}$ and $\mathrm{NO}_{3}{ }^{-}$sorption on $\mathrm{EBS}$, which is a physisorption-dominated process.

Table 3. Parameters of $\mathrm{NO}_{3}{ }^{-}$adsorption kinetics of different biochars.

\begin{tabular}{|c|c|c|c|c|c|c|c|c|c|}
\hline \multirow{2}{*}{ Sample } & \multicolumn{3}{|c|}{ Pseudo-First-Order } & \multicolumn{3}{|c|}{ Pseudo-Second-Order } & \multicolumn{3}{|c|}{ Intra-Particle Diffusion } \\
\hline & $\begin{array}{c}K_{1} \\
\left(h^{-1}\right)\end{array}$ & $\begin{array}{c}q_{\mathrm{e}} \\
\left(\mathrm{mg} \mathrm{g}^{-1}\right)\end{array}$ & $\mathbf{R}^{2}$ & $\begin{array}{c}\mathrm{K}_{2} \\
\left(\mathrm{~g} \mathrm{mg}^{-1} \mathrm{~h}^{-1}\right)\end{array}$ & $\begin{array}{c}\mathrm{qe}_{\mathrm{e}} \\
\left(\mathrm{mg} \mathrm{g}^{-1}\right)\end{array}$ & $\mathbf{R}^{2}$ & $\begin{array}{c}\mathrm{K}_{3} \\
\left(\mathrm{mg} \mathrm{g}^{-1} \mathrm{~h}^{-0.5}\right)\end{array}$ & $\begin{array}{c}\mathrm{C} \\
\left(\mathrm{mg} \mathrm{g}^{-1}\right)\end{array}$ & $\mathbf{R}^{2}$ \\
\hline PCB300 & 0.001 & 0.028 & 0.764 & 0.153 & 0.053 & 0.984 & 0.001 & 0.015 & 0.771 \\
\hline SDB300 & 0.001 & 0.023 & 0.700 & 0.287 & 0.216 & 0.992 & 0.001 & 0.177 & 0.328 \\
\hline SDB500 & 0.006 & 0.300 & 0.968 & 0.010 & 0.267 & 0.974 & 0.006 & -0.002 & 0.928 \\
\hline ESB300 & 0.004 & 0.047 & 0.970 & 0.449 & 0.044 & 0.966 & 0.002 & -0.009 & 0.804 \\
\hline ESB500 & 0.008 & 0.127 & 0.906 & 0.097 & 0.05 & 0.878 & 0.003 & -0.021 & 0.814 \\
\hline ESB700 & 0.003 & 0.193 & 0.989 & 0.024 & 0.112 & 0.935 & 0.005 & -0.036 & 0.914 \\
\hline
\end{tabular}

\subsection{Sorption Isotherms of Biochar}

The amount of $\mathrm{P}$ adsorption by RSB700 increased with $\mathrm{P}$ concentration in the initial solution. Release of P from RSB300 and RSB500 occurred when P concentration was $<80 \mathrm{mg} \mathrm{L}^{-1}$ in the 
initial solution (Figure 3a). The amount of P adsorption by PCB300 and PCB500 increased with P concentration in the initial solution (Figure 3b). However, release of P from PCB700 occurred for different $P$ concentrations in the initial solution (Figure 3b). Zhang et al. [19] showed that timber biochar and peanut shell biochar released $\mathrm{P}$ when the $\mathrm{P}$ concentration was $<100 \mathrm{mg} \mathrm{P} \mathrm{L}^{-1}$, but they retained 1-2\% $\mathrm{P}$ when the $\mathrm{P}$ concentration in the solution was $200 \mathrm{mg} \mathrm{P} \mathrm{L}^{-1}$. It can be seen from Figure 3c that SDB300, SDB500 and SDB700 released $P$ when the $P$ concentration was $<5 \mathrm{mg} \mathrm{L}^{-1}$, but they adsorbed $\mathrm{P}$ when $\mathrm{P}$ concentration was $>80 \mathrm{mg} \mathrm{L}^{-1}$. Therefore, the $\mathrm{P}$ adsorption capacity of the biochars was influenced by the $\mathrm{P}$ concentration in the initial solution. These results are similar to those of Chintala et al. [22], who demonstrated that $\mathrm{P}$ adsorption on biochars was significantly affected by initial P concentration and biochar types. According to Figure 3d, ESB300, ESB500 and ESB700 had a capacity to adsorb P, and ESB700 exhibited the highest P sorption capacity.

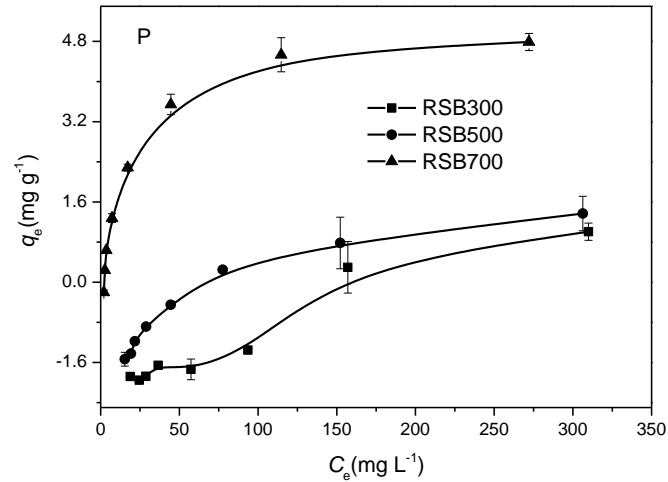

(a)

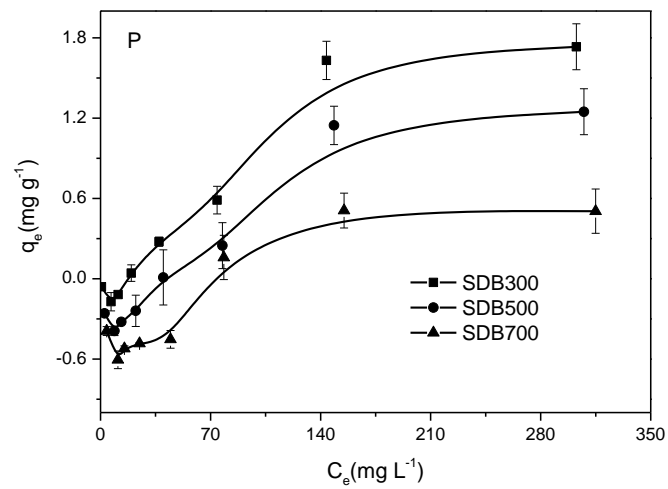

(c)

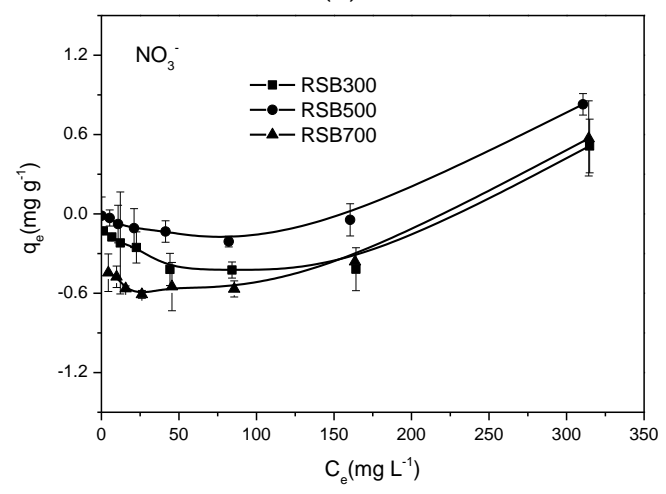

(e)

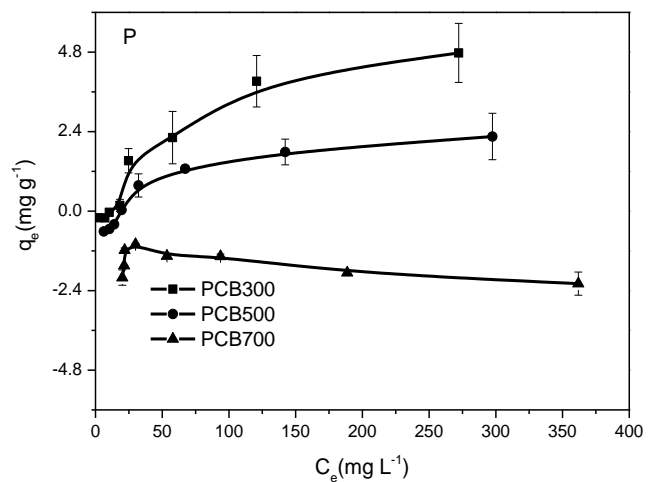

(b)

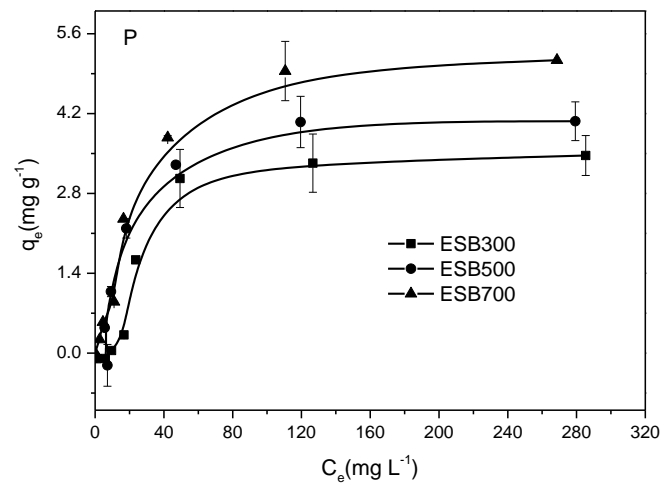

(d)

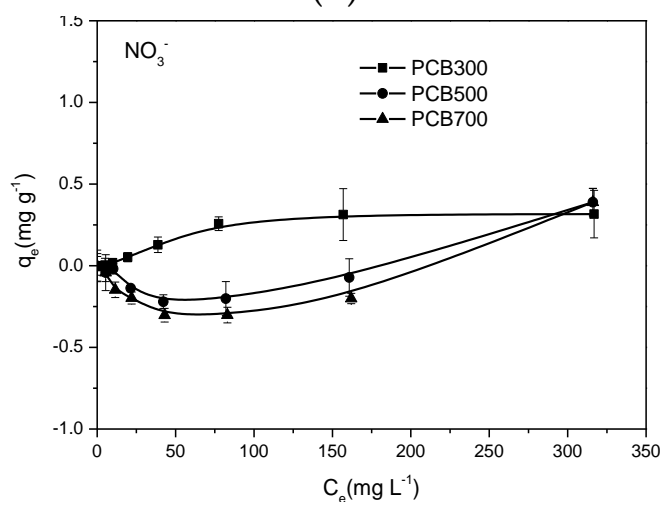

(f)

Figure 3. Cont. 


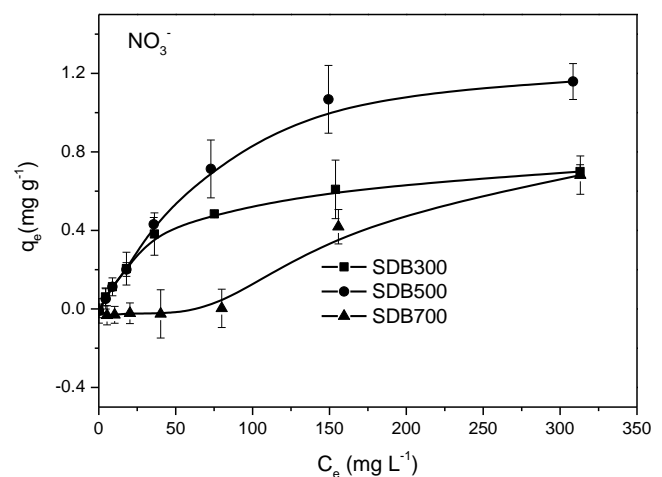

(g)

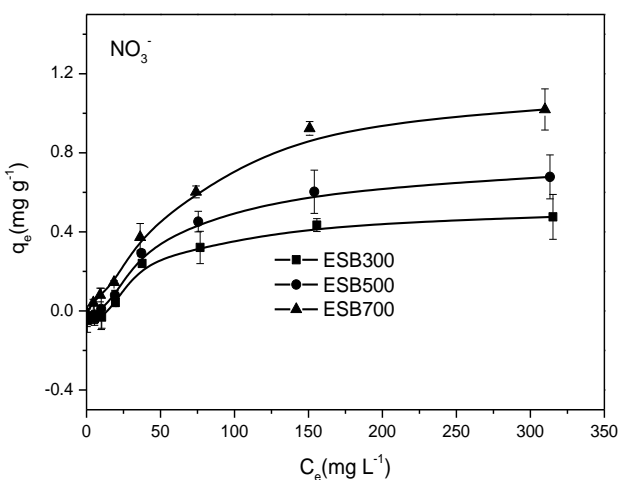

(h)

Figure 3. Adsorption isotherms of $\mathrm{P}$ and $\mathrm{NO}_{3}{ }^{-}$on $\mathrm{RSB}(\mathbf{a}), \mathrm{PCB}(\mathbf{b}), \mathrm{SDB}(\mathbf{c}), \mathrm{ESB}(\mathbf{d}), \mathrm{RSB}(\mathbf{e}), \mathrm{PCB}(\mathbf{f})$, $\operatorname{SDB}(\mathbf{g})$, and $\operatorname{ESB}(\mathbf{h})$, respectively. Data are means $\pm \operatorname{SD}$ of $n=3$.

It can be seen from Figure 3e,f, RSB and PCB cannot adsorb $\mathrm{NO}_{3}{ }^{-}$in the lower initial $\mathrm{NO}_{3}{ }^{-}$ concentration. The results are similar to those of Hale et al. [15], who found that cacao-shell derived biochar could not adsorb $\mathrm{NO}_{3}{ }^{-}$. The amount of adsorption $\mathrm{NO}_{3}{ }^{-}$on SDB and ESB increased with initial $\mathrm{NO}_{3}{ }^{-}$concentration (Figure 3g,h). The order of $\mathrm{NO}_{3}{ }^{-}$adsorption capacity on ESB was that of ESB700 $>$ ESB500 $>$ ESB300 (Figure 3h). However, the order of $\mathrm{NO}_{3}{ }^{-}$adsorption on SDB was shown as following: SDB500 > SDB300 > SDB700 (Figure 3g). These results showed that the $\mathrm{NO}_{3}{ }^{-}$adsorption capacity on biochars was also influenced by types of biochar and pyrolysis temperatures.

RSB700, PCB300, PCB500, SDB300, SDB500, and ESB have the ability to adsorb P from P solutions, so their $\mathrm{P}$ adsorption isotherms were investigated to elucidate the adsorption mechanisms. The model parameters for $\mathrm{P}$ on biochars for both Langmuir and Freundlich models are presented in Table 4, which show that the Langmuir model fits the experimental data better $\left(0.981>R^{2}>0.852\right)$ than the Freundlich model (0.897 $\left.>\mathrm{R}^{2}>0.728\right)$. Similarly, PCB300, SDB300, SDB500, ESB300, ESB500 and ESB700 have the ability to adsorb $\mathrm{NO}_{3}{ }^{-}$. Therefore, their model parameters for $\mathrm{NO}_{3}{ }^{-}$on biochars for both Langmuir and Freundlich models are presented in Table 5, which show that the Langmuir model fits the experimental data better $\left(0.996>R^{2}>0.919\right)$ than the Freundlich model $\left(0.949>R^{2}>0.850\right)$. Therefore, the Langmuir equation fitted the data better than the Freundlich equation for adsorption $\mathrm{P}$ and $\mathrm{NO}_{3}{ }^{-}$(Tables 4 and 5). This is consistent with Tan et al. [28], who showed that the Langmuir equation had the best fit for the experiment. Elsa et al. [25] demonstrated that the Freundlich constant $\left(K_{F}\right)$ increased with the calcium content, which confirms the increase in adsorption intensity of the biochar due to the chemical reaction between phosphate ions and $\mathrm{Ca}^{2+}$. In this study, $\mathrm{K}_{\mathrm{F}}$ for $\mathrm{P}$ and $\mathrm{NO}_{3}{ }^{-}$adsorption on ESB increased with pyrolysis temperature.

Table 4. Parameters of $\mathrm{P}$ adsorption isotherms of different biochars.

\begin{tabular}{|c|c|c|c|c|c|c|}
\hline \multirow{2}{*}{ Sample } & \multicolumn{3}{|c|}{ Langmuir } & \multicolumn{3}{|c|}{ Freundlich } \\
\hline & $\underset{\left(\mathrm{mg} \mathrm{g}^{-1}\right)}{q_{\max }}$ & $\begin{array}{c}K_{L} \\
\left(\mathrm{~L} \mathrm{mg}^{-1}\right)\end{array}$ & $\mathbf{R}^{2}$ & $\begin{array}{c}K_{F} \\
\left(\mathrm{mg} \mathrm{g}^{-1}\right)\end{array}$ & $\mathbf{n}$ & $\mathbf{R}^{2}$ \\
\hline RSB700 & 5.407 & 0.039 & 0.981 & 0.611 & 2.558 & 0.876 \\
\hline РCB300 & 7.747 & 0.007 & 0.942 & 0.125 & 1.501 & 0.897 \\
\hline PCB500 & 3.270 & 0.008 & 0.933 & 0.026 & 1.246 & 0.760 \\
\hline SDB300 & 3.859 & 0.003 & 0.903 & 0.019 & 1.230 & 0.872 \\
\hline SDB500 & 3.395 & 0.002 & 0.911 & 0.002 & 0.871 & 0.728 \\
\hline ESB300 & 4.538 & 0.018 & 0.852 & 0.244 & 2.009 & 0.760 \\
\hline ESB500 & 4.922 & 0.030 & 0.920 & 0.482 & 2.458 & 0.800 \\
\hline ESB700 & 6.084 & 0.031 & 0.973 & 0.598 & 2.542 & 0.855 \\
\hline
\end{tabular}


Table 5. Parameters of $\mathrm{NO}_{3}{ }^{-}$adsorption isotherms of different biochar.

\begin{tabular}{ccccccc}
\hline \multirow{2}{*}{ Sample } & \multicolumn{3}{c}{ Langmuir } & \multicolumn{3}{c}{ Freundlich } \\
\cline { 2 - 7 } & $\begin{array}{c}\boldsymbol{q}_{\text {max }} \\
\left(\mathbf{m g ~ g}^{-\mathbf{1}}\right)\end{array}$ & $\begin{array}{c}\boldsymbol{K}_{\mathbf{L}} \\
\left(\mathbf{L ~} \mathbf{~ g}^{-\mathbf{1}}\right)\end{array}$ & $\mathbf{R}^{\mathbf{2}}$ & $\begin{array}{c}\boldsymbol{K}_{\boldsymbol{F}} \\
\left(\mathbf{m g ~ g}^{-\mathbf{1}} \mathbf{)}\right.\end{array}$ & $\mathbf{n}$ & $\mathbf{R}^{\mathbf{2}}$ \\
\hline PCB300 & 0.433 & 0.012 & 0.955 & 0.021 & 2.006 & 0.876 \\
SDB300 & 0.804 & 0.021 & 0.996 & 0.070 & 2.416 & 0.949 \\
SDB500 & 1.574 & 0.011 & 0.989 & 0.067 & 1.941 & 0.941 \\
ESB300 & 0.671 & 0.010 & 0.919 & 0.020 & 1.735 & 0.850 \\
ESB500 & 0.937 & 0.010 & 0.963 & 0.032 & 1.810 & 0.901 \\
ESB700 & 1.426 & 0.010 & 0.987 & 0.051 & 1.855 & 0.941 \\
\hline
\end{tabular}

The maximum adsorption of $\mathrm{P}$ and $\mathrm{NO}_{3}{ }^{-}\left(q_{\max }\right)$ on ESB was lower in the biochar produced through pyrolysis at $300{ }^{\circ} \mathrm{C}$ than at $700{ }^{\circ} \mathrm{C}$ (Tables 4 and 5), indicating that the maximum adsorption of $\mathrm{P}$ and $\mathrm{NO}_{3}{ }^{-}$increased with pyrolysis temperature. Our results are similar to those of Zhang et al. [20], who found that biochar, produced from horse manure and bedding compost at pyrolysis of $200{ }^{\circ} \mathrm{C}$, released the $\mathrm{P}$ and $\mathrm{NO}_{3}{ }^{-}$. However, the maximum adsorption of $\mathrm{P}\left(q_{\max }\right)$ on PCB and SDB was lower in the biochar produced at pyrolysis temperature of $500{ }^{\circ} \mathrm{C}$ than at $300^{\circ} \mathrm{C}$. Therefore, the maximum adsorption of $\mathrm{P}$ on biochar was influenced by pyrolysis temperature. The maximum adsorption of $\mathrm{P}$ $\left(q_{\max }\right)$ on RSB700, PCB300, SDB300 and ESB700 was 5.407, 7.747, 3.859 and $6.084 \mathrm{mg} \mathrm{g}^{-1}$, respectively. The maximum adsorption of $\mathrm{P}\left(q_{\max }\right)$ on PCB300 was approximately two times that of SDB300. The maximum adsorption of $\mathrm{NO}_{3}{ }^{-}\left(q_{\max }\right)$ on PCB300, SDB300 and ESB700 was $0.443,1.574$ and $1.426 \mathrm{mg} \mathrm{g}^{-1}$, respectively. Kameyama et al. [21] found that only 1.2 and $0.7 \mathrm{mg} \mathrm{g}^{-1} \mathrm{NO}_{3}{ }^{-}$could be adsorbed by the bamboo powder charcoal and sugarcane bagasse derived biochar, respectively. In this study, the $\mathrm{NO}_{3}{ }^{-}$ adsorption capacity was between 0.443 to $1.426 \mathrm{mg} \mathrm{g}^{-1}$. Therefore, the capacity to absorb $\mathrm{NO}_{3}{ }^{-}$was lower but varied with the biochars from different feedstock materials.

\subsection{Adsorption Thermodynamics of Biochars}

The thermodynamics of $\mathrm{P}$ and $\mathrm{NO}_{3}{ }^{-}$adsorption on the biochars at 293, 303, and $313 \mathrm{~K}$ were analyzed (Figures 4 and 5). As shown in Table 6, the $\Delta H^{0}$ value for RSB700, PCB300, SDB300 and ESB700 was $83.54,44.63,27.53$ and $39.68 \mathrm{~kJ} \mathrm{~mol}^{-1}$, respectively, indicating that $\mathrm{P}$ adsorption process was endothermic. The $\Delta S^{0}$ value for RSB700, PCB300, SDB300 and ESB700 was 0.33, 0.19, 0.13 and $0.19 \mathrm{~kJ} \mathrm{~mol}^{-1} \mathrm{~K}^{-1}$, respectively, indicating increased disorder and randomness of liquid-solid phase interaction at the biochar surface [29]. Zhang et al. [30] demonstrated that $\mathrm{P}$ tended to be adsorbed on the surface of biochar when the $\Delta S^{0}$ values were positive. The $\Delta G^{0}$ values were in a range of -10.48 to $-18.41 \mathrm{~kJ} \mathrm{~mol}^{-1}$ indicating that the process of $\mathrm{PO}_{4}{ }^{3-}$ adsorption onto the biochar was mainly spontaneous [31,32]. Furthermore, the $\Delta G^{0}$ decreased with increasing adsorption reaction temperature, indicating a better $\mathrm{P}$ adsorption efficiency at a higher solution temperature [33].

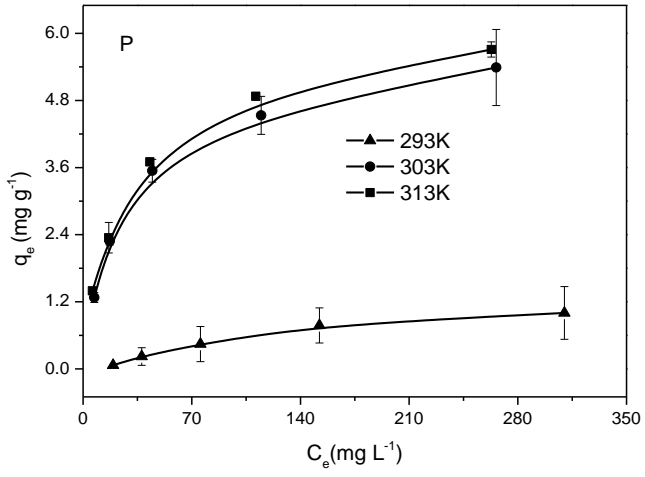

(a)

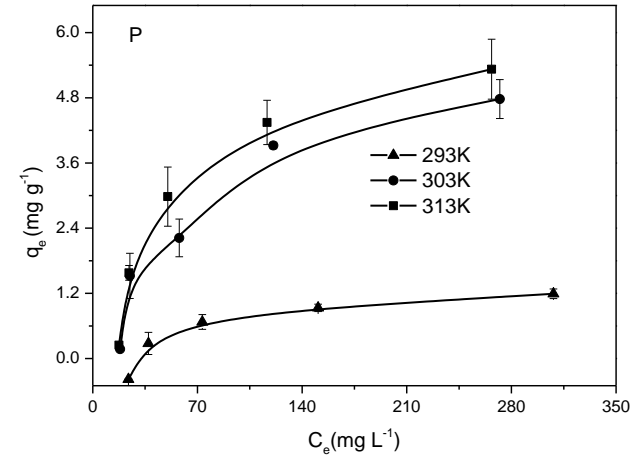

(b)

Figure 4. Cont. 


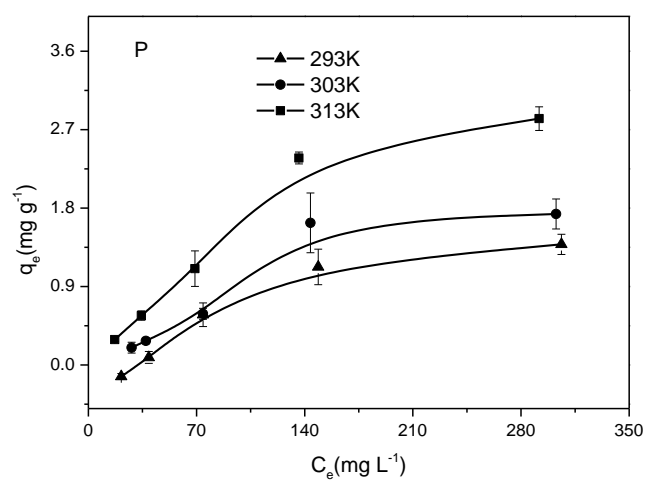

(c)

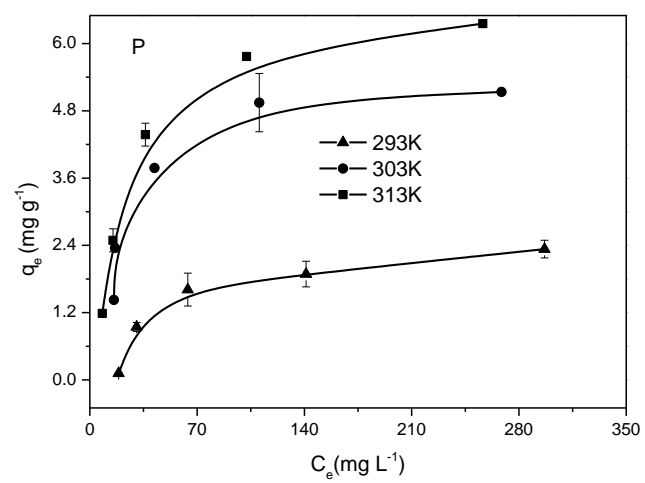

(d)

Figure 4. Amount of P on RSB700 (a), PCB300 (b), SDB300 (c) and ESB700 (d) under different temperature. Data are means $\pm \mathrm{SD}$ of $n=3$.

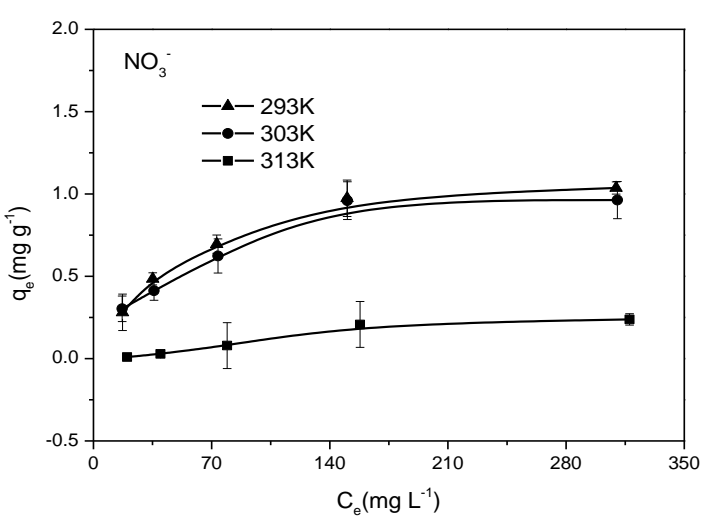

(a)

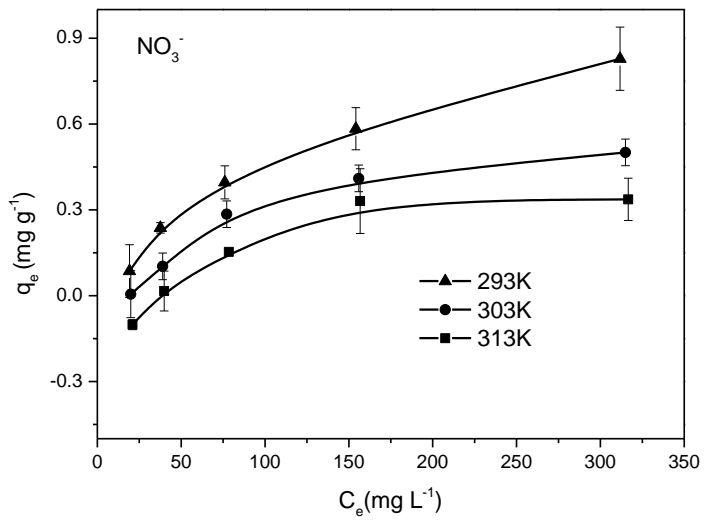

(c)

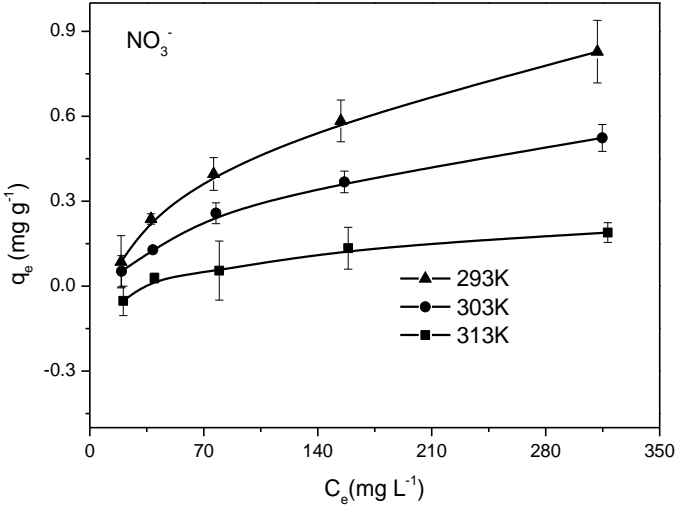

(b)

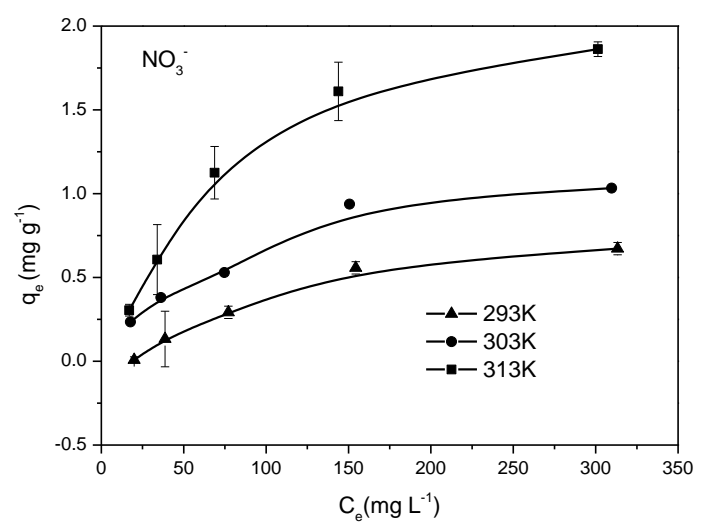

(d)

Figure 5. Amount of $\mathrm{NO}_{3}{ }^{-}$on RSB500 (a), PCB300 (b), SDB500 (c) and ESB300 (d) under different temperature, respectively. Data are means $\pm \operatorname{SD}$ of $n=3$. 
Table 6. Thermodynamic parameters for $\mathrm{P}$ and $\mathrm{NO}_{3}{ }^{-}$adsorption.

\begin{tabular}{|c|c|c|c|c|c|c|c|c|}
\hline \multirow[b]{2}{*}{$\mathrm{T}(\mathrm{K})$} & \multicolumn{5}{|c|}{$\mathbf{P}$} & \multicolumn{3}{|c|}{$\mathrm{NO}_{3}{ }^{-}$} \\
\hline & Sample & $\begin{array}{c}\Delta H^{0} \\
\left(\mathrm{~kJ} \mathrm{~mol}^{-1}\right)\end{array}$ & $\begin{array}{c}\Delta S^{0} \\
\left(\mathrm{~kJ} \mathrm{~mol} \mathbf{l}^{-1} \mathrm{~K}^{-1}\right)\end{array}$ & $\begin{array}{c}G^{0} \\
\left(\mathrm{~kJ} \mathrm{~mol}^{-1}\right)\end{array}$ & Sample & $\begin{array}{c}\Delta H^{0} \\
\left(\mathrm{~kJ} \mathrm{~mol}^{-1}\right)\end{array}$ & $\begin{array}{c}\Delta S^{0} \\
\left(\mathrm{~kJ} \mathrm{~mol}^{-1} \mathrm{~K}^{-1}\right)\end{array}$ & $\begin{array}{c}\Delta G^{0} \\
\left(\mathrm{~kJ} \mathrm{~mol}^{-1}\right)\end{array}$ \\
\hline 293 & RSB700 & & & -11.95 & RSB500 & -70.80 & -0.19 & -13.47 \\
\hline 303 & & 83.54 & 0.33 & -17.70 & & & & -12.69 \\
\hline 313 & & & & -18.41 & & & & -9.73 \\
\hline 293 & PCB300 & & & -11.27 & PCB300 & -25.37 & -0.05 & -10.79 \\
\hline 303 & & 44.63 & 0.19 & -13.92 & & & & -10.70 \\
\hline 313 & & & & -15.07 & & & & -9.73 \\
\hline 293 & SDB300 & & & -10.48 & SDB500 & -27.44 & -0.06 & -10.79 \\
\hline 303 & & 27.53 & 0.13 & -11.99 & & & & -10.70 \\
\hline 313 & & & & -13.07 & & & & -8.67 \\
\hline 293 & ESB700 & & & -14.53 & ESB300 & 39.20 & 0.17 & -9.81 \\
\hline 303 & & 39.68 & 0.19 & -17.47 & & & & -12.45 \\
\hline 313 & & & & -18.20 & & & & -13.11 \\
\hline
\end{tabular}

The $\Delta H^{0}$ value for RSB500, PCB300 and SDB500 was $-70.8,-25.37$ and $-27.44 \mathrm{~kJ} \mathrm{~mol}^{-1}$ (Table 6), respectively, indicating that $\mathrm{NO}_{3}{ }^{-}$adsorption process was an exothermic reaction. However, the $\Delta \mathrm{H}^{\circ}$ value for ESB was 39.2, indicating this was endothermic. The $\Delta S^{0}$ value for RSB, PCB and SDB was $-0.19,-0.05$, and $-0.06 \mathrm{~kJ} \mathrm{~mol}^{-1} \mathrm{k}^{-1}$, respectively, indicating decreased disorder. However, the $\Delta S^{0}$ value for ESB was $0.17 \mathrm{~kJ} \mathrm{~mol}^{-1} \mathrm{k}^{-1}$, suggesting increased disorder. The $\Delta G^{0}$ values were in the range of -8.67 to $-13.47 \mathrm{~kJ} \mathrm{~mol}^{-1}$ indicating that the process of $\mathrm{NO}_{3}{ }^{-}$adsorption onto the biochars was also spontaneous in nature. The $\Delta G^{0}$ of RSB, PCB and SDB increased with adsorption reaction temperatures, indicating a better $\mathrm{NO}_{3}{ }^{-}$adsorption efficiency at a lower solution temperature. However, the $\Delta G^{0}$ of ESB decreased with increasing adsorption reaction temperature, indicating a better $\mathrm{NO}_{3}{ }^{-}$adsorption efficiency at a higher solution temperature [33]. Results show that $\mathrm{NO}_{3}{ }^{-}$adsorption process on the biochars produced from feedstocks rich in cellulose, hemicellulose and lignin was an exothermic reaction, but an endothermic reaction occurred for the biochar produced from egg shell.

\subsection{Effect of Characteristic of Biochar on Capacity of Nitrate and Phosphate Adsorption}

Cellulose, hemicellulose, and lignin are essential constituents of plant cell walls. In this study, RSB, PCB and SDB derived from the plants waste showed limited adsorption of, or even released, $\mathrm{NO}_{3}{ }^{-}$and $\mathrm{P}$. These findings agree with Zhang et al. [34] who found that the pristine biochar surface is negatively charged, and thus cannot easily adsorb the negatively charged $\mathrm{NO}_{3}{ }^{-}$and P. Plant-derived biochar used in this study had a low zeta potential $(-16.6$ to $-41.9 \mathrm{mV})$, meaning that electrostatic repulsion between the negatively charged surface sites and electronegative phosphate species resulted in the lower phosphate adsorption [35]. Yang et al. [36] demonstrated that positive zeta potential is desirable to the adsorption of anion by electrostatic attraction and in this study egg shell biochar (ESB) had a positive zeta potential in the range -2.9 to $-4.9 \mathrm{mV}$.

The $\mathrm{NO}_{3}{ }^{-}$and $\mathrm{P}$ adsorption capacity of egg shell biochar was influenced by surface area and porosity characteristic. The SEM images of ESB showed that there was more porosity of ESB produced at $700{ }^{\circ} \mathrm{C}$ than at $300{ }^{\circ} \mathrm{C}$ (Figure 1). The $\mathrm{P}$ and $\mathrm{NO}_{3}{ }^{-}$adsorption capacities were higher in ESB700 than in ESB300, which was related to more porous structure and higher surface area in ESB700 than in ESB300 (Table 1). These findings agreed with those of Yin et al. [37], who demonstrated that the porous structure and higher surface area could contribute to better $\mathrm{PO}_{4}{ }^{3-}$ and $\mathrm{NO}_{3}{ }^{-}$adsorption. Therefore, the higher surface area of egg shell biochar seems to improve adsorption of $\mathrm{NO}_{3}{ }^{-}$and $\mathrm{P}$.

The $\mathrm{NO}_{3}{ }^{-}$and $\mathrm{P}$ adsorption capacity of biochars could be improved by adjusting pyrolysis temperature. Many methods have been used to improve $\mathrm{NO}_{3}{ }^{-}$and $\mathrm{P}$ adsorption capacity. It was reported that the dashed activated carbon could adsorb $9.84 \mathrm{mg} \mathrm{NO}_{3}{ }^{-} \mathrm{g}^{-1}$ [38]. The $\mathrm{NO}_{3}{ }^{-}$adsorption on the La-modified biochar was $8.81 \mathrm{mg} \mathrm{g}^{-1}$, which was considerably higher than that on the pristine biochar ( $\left.2.81 \mathrm{mg} \mathrm{g}^{-1}\right)$ [39]. The Mg-modified sugar beet tailing biochar showed a P adsorption capacity of $6.67 \mathrm{mg} \mathrm{g}^{-1}$ [35]. The sesame straw biochar activated by $\mathrm{ZnCl}_{2}$ showed the highest phosphorus adsorption capacity of $9.39 \mathrm{mg} \mathrm{g}^{-1}$ [40]. The poplar chips biochar modified by Al showed its high $\mathrm{P}$ 
adsorption capacity of $43.98 \mathrm{mg} \mathrm{g}^{-1}$ [37]. Results of this study showed that the $\mathrm{NO}_{3}{ }^{-}$and $\mathrm{P}$ adsorption capacity could be enhanced by adjusting pyrolysis temperature. For example, the maximum sorption of $\mathrm{P}$ on RSB, produced at pyrolysis temperature of $700{ }^{\circ} \mathrm{C}$, was $5.40 \mathrm{mg} \mathrm{g}^{-1}$. Compared with RSB300 and RSB500, RSB700 with higher P adsorption capacity could be attributed to higher surface area and total volume (Table 1). Similarly, the maximum sorption of $\mathrm{NO}_{3}{ }^{-}$on $\mathrm{SDB}$, derived from pyrolysis at $300{ }^{\circ} \mathrm{C}$, was $1.574 \mathrm{mg} \mathrm{g}^{-1}$. Iida et al. [38] demonstrated that the $\mathrm{NO}_{3}{ }^{-}$adsorption process would be restricted under basic conditions because the $\mathrm{OH}^{-}$competes with $\mathrm{NO}_{3}{ }^{-}$for the adsorption sites on the biochar surface. Ketcha et al. [41] also found that the optimum $\mathrm{pH}$ value of $\mathrm{NO}_{3}{ }^{-}$adsorption on activated carbon was in the range of 2.8-6.5. Therefore, the ability of SDB300 to adsorb $\mathrm{NO}_{3}{ }^{-}$could be related to their lower $\mathrm{pH}$ derived from pyrolysis at $300{ }^{\circ} \mathrm{C}$ (Table 1). Results suggested that the $\mathrm{P}$ and $\mathrm{NO}_{3}{ }^{-}$adsorption capacity could be improved through screening biochars derived from different feedstock materials and pyrolysis temperatures.

\section{Conclusions}

The physicochemical characteristics of biochars were influenced by feedstock type and pyrolysis temperature, which affected the $\mathrm{N}$ and $\mathrm{P}$ adsorption capacity. Biochars derived from plant wastes, including RSB, $\mathrm{PCB}$ and SDB, had limited adsorption or even released $\mathrm{NO}_{3}{ }^{-}$and $\mathrm{P}$. However, their $\mathrm{PO}_{4}{ }^{3-}$ adsorption capacity improved by adjusting pyrolysis temperature. Egg shell biochar (ESB) has an ability to adsorption both $\mathrm{NO}_{3}{ }^{-}$and $\mathrm{P}$, which increased with increasing pyrolysis temperatures. The maximum $\mathrm{NO}_{3}{ }^{-}$and $\mathrm{P}$ adsorption on ESB700, produced at pyrolysis temperature of $700{ }^{\circ} \mathrm{C}$ was 1.426 and $6.084 \mathrm{mg} \mathrm{g}^{-1}$, respectively. Surface area and zeta potential of ESB could be the two predominant factors affecting $\mathrm{NO}_{3}{ }^{-}$and $\mathrm{P}$ adsorption. The influences of pyrolysis temperature on adsorption of both $\mathrm{NO}_{3}{ }^{-}$and $\mathrm{P}$ varied between feedstock materials.

Author Contributions: L.Z., Q.P., and J.W. carried out the data analysis; D.X. and Y.L. wrote the manuscript; L.X. and A.H. revised it.

Funding: This research was funded by the Key Laboratory of Agro-Environment in downstream of Yangze Plain, Ministry of Agriculture, P. R. China (AE2018001), Six Talent Peaks Project in Jiangsu Province (JNHB-057), and Qing Lan Project (20161507).

Conflicts of Interest: The authors declare no conflict of interest.

\section{References}

1. Barcellos, D.; Queiroz, H.M.; Nóbrega, G.N.; De Oliveira Filho, R.L.; Santaella, S.T.; Otero, X.L.; Ferreira, T.O. Phosphorus enriched effluents increase eutrophication risks for mangrove systems in northeastern Brazil. Mar. Pollut. Bull. 2019, 142, 58-63. [CrossRef]

2. Yang, Y.Y.; Chen, J.F.; Tong, T.L.; Li, B.Q.; He, T.; Liu, Y.; Xie, S.G. Eutrophication influences methanotrophic activity, abundance and community structure in freshwater lakes. Sci. Total Environ. 2019, 662, 863-872. [CrossRef]

3. Karaca, S.; Gurses, A.; Ejder, M.; Acikyildiz, M. Kinetic modeling of liquid phase adsorption of phosphate on dolomite. J. Colloid Interface Sci. 2004, 277, 257-263. [CrossRef]

4. Yin, Q.; Zhang, B.; Wang, R.; Zhao, Z. Biochar as an adsorbent for inorganic nitrogen and phosphorus removal from water: A review. Environ. Sci. Pollut. Res. 2017, 24, 26297-26309. [CrossRef]

5. Wang, D.B.; Yang, G.J.; Li, X.M.; Zheng, W.; Wu, Y.; Yang, Q.; Zeng, G.M. Inducing mechanism of biological phosphorus removal driven by the aerobic/extended-idle regime. Biotechnol. Bioeng. 2012, 109, $2798-2807$. [CrossRef]

6. Yao, Y.; Gao, B.; Inyang, M.; Zimmerman, A.R.; Cao, X.D.; Pullammanappallil, P.; Yang, L.Y. Removal of phosphate from aqueous solution by biochar derived from anaerobically digested sugar beet tailings. J. Hazard. Mater. 2011, 190, 501-507. [CrossRef]

7. Neufeld, R.D.; Thodos, G. Removal of orthophosphates from aqueous solutions with activated alumina. Environ. Sci. Technol. 1969, 3, 661-667. [CrossRef] 
8. Hossein, K.; Masoud, S.N.; Hamed, S.; Hossein, S.H. Facile reduction of graphene using urea in solid phase and surface modification by N-doped graphene quantum dots for adsorption of organic dyes. Diam Relat. Mater. 2017, 79, 133-144.

9. Bhatnagar, A.; Sillanpää, M. A review of emerging adsorbents for nitrate removal from water. Chem. Eng. J. 2011, 168, 493-504. [CrossRef]

10. Doula, M.K.; Sarris, A.; Hliaoutakis, A.; Kydonakis, A.; Papadopoulos, N.S.; Argyriou, L. Building a strategy for soil protection at local and regional scale-the case of agricultural wastes land spreading. Environ. Monit. Assess. 2016, 188, 114. [CrossRef]

11. Liu, Z.; Zhou, X.; Chen, X.; Dai, C.; Zhang, J.; Zhang, Y. Biosorption of clofibric acid and carbamazepine in aqueous solution by agricultural waste rice straw. J. Environ. Sci. 2013, 25, 2384-2395. [CrossRef]

12. He, J.W.; Yang, S.M.; Zhang, G.Y. Recent studies on eggshell as adsorption material. Trans. Chin. Soc. Agric. Eng. 2016, 32, 297-303.

13. Badr, A.M.; Naoko, E.; Chang, S.K.; Bi, X.T. The role of tailored biochar in increasing plant growth, and reducing bioavailability, phytotoxicity, and uptake of heavy metals in contaminated soil. Environ. Pollut. 2017, 230, 329-338.

14. Yao, Y.; Gao, B.; Zhang, M.; Inyang, M.; Zimmerman, A.R. Effect of biochar amendment on sorption and leaching of nitrate, ammonium, and phosphate in a sandy soil. Chemosphere 2012, 89, 146-1471. [CrossRef]

15. Hale, S.E.; Alling, V.; Martinsen, V.; Mulder, J.; Breedveld, G.D.; Cornelissen, G. The sorption and desorption of phosphate-P ammonium-N and nitrate-N in cacao shell and corn cob biochars. Chemosphere 2013, 91, 1612-1619. [CrossRef]

16. Jung, K.W.; Kyu-Hong, A. Fabrication of porosity-enhanced MgO/biochar for removal of phosphate from aqueous solution: Application of a novel combined electrochemical modification method. Bioresour. Technol. 2016, 200, 1029-1032. [CrossRef]

17. Michalekova-Richveisova, B.; Fristak, V.; Pipiska, M.; Duriska, L.; Moreno-Jimenez, E.; Soja, G. Iron-impregnated biochars as effective phosphate sorption materials. Environ. Sci. Pollut. Res. Int. 2017, 24, 463-475. [CrossRef]

18. Novais, S.V.; Zenero, M.D.O.; Barreto, M.S.C.; Montes, C.R.; Cerri, C.E.P. Phosphorus removal from eutrophic water using modified biochar. Sci. Total Environ. 2018, 633, 825-835. [CrossRef]

19. Zhang, H.Z.; Chen, C.R.; Evan, M.G.; Sue, E.B.; Yang, H.; Zhang, D.K. Roles of biochar in improving phosphorus availability in soils: A phosphate adsorbent and a source of available phosphorus. Geoderma 2016, 276, 1-6. [CrossRef]

20. Zhang, H.; Voroney, R.P.; Price, G.W. Effects of temperature and activation on biochar chemical properties and their impact on ammonium, nitrate, and phosphate sorption. J. Environ. Qual. 2017, 46, 889-896. [CrossRef]

21. Kameyama, K.; Miyamoto, T.; Shiono, T.; Shinogi, Y. Influence of sugarcane bagasse-derived biochar application on nitrate leaching in calcaric dark red soil. J. Environ. Qual. 2012, 41, 1131-1137. [CrossRef]

22. Chintala, R.; Schumacher, T.E.; McDonald, L.M.; Clay, D.E.; Malo, D.D.; Papiernik, S.K.; Clay, S.A.; Julson, J.L. Phosphorus sorption and availability from biochars and soil/biochar mixtures. Clean Soil Air Water 2014, 42, 626-634. [CrossRef]

23. Novais, S.V.; Zenero, M.D.O.; Tronto, J.; Conz, R.F.; Cerri, C.E.P. Poultry manure and sugarcane straw biochars modified with $\mathrm{MgCl}_{2}$ for phosphorus adsorption. J. Environ. Manag. 2018, 214, 36-44. [CrossRef]

24. Schneider, F.; Haderlein, S.B. Potential effects of biochar on the availability of phosphorus-mechanistic insights. Geoderma 2016, 277, 83-90. [CrossRef]

25. Elsa, A.; Mohan, V.J.; Graham, B.; Philip, A.S. Isotherms, kinetics and mechanism analysis of phosphorus recovery from aqueous solution by calcium-rich biochar produced from biosolids via microwave pyrolysis. J. Environ. Chem. Eng. 2018, 6, 395-403.

26. Yin, Q.Q.; Wang, R.K.; Zhao, Z.H. Application of Mg-Al-modified biochar for simultaneous removal of ammonium, nitrate, and phosphate from eutrophic water. J. Clean Prod. 2018, 176, 230-240. [CrossRef]

27. Wang, S.D.; Kong, L.J.; Long, J.Y.; Su, M.H.; Diao, Z.H.; Chang, X.Y.; Chen, D.Y.; Song, G.; Kaimin, S. Adsorption of phosphorus by calcium-flour biochar: Isotherm, kinetic and transformation studies. Chemosphere 2018, 195, 666-672. [CrossRef]

28. Tan, I.A.; Ahmad, A.L.; Hameed, B.H. Adsorption of basic dye on high-surface-area activated carbon prepared from coconut husk: Equilibrium, kinetic and thermodynamic studies. J. Hazard. Mater. 2008, 154, 337-346. [CrossRef] 
29. Hema, M.; Arivoli, S. Comparative study on the adsorption kinetics and thermodynamics of dyes onto acid activated low cost carbon. Int. J. Phys. Sci. 2007, 2, 10-17.

30. Zhang, T.; Xu, H.Y.; Li, H.H.; He, X.Y.; Shi, Y.J.; Andrea, K. Microwave digestion-assisted HFO/Biochar adsorption to recover phosphorus from swine manure. Sci. Total Environ. 2018, 621, 1512-1526. [CrossRef]

31. Qu, B.; Zhou, J.; Xiang, X.; Zheng, C.; Zhao, H.; Zhou, X. Adsorption behavior of Azo Dye, CI Acid Red 14 in aqueous solution on surface soils. J. Environ. Sci. 2008, 20, 704-709. [CrossRef]

32. Simon, K.; Wu, S.B.; Kirui, W.K.; Lei, M.; Lu, Q.M.; Bah, H.D.; Dong, R.J. Evaluation of slow pyrolyzed wood and rice husks biochar for adsorption of ammonium nitrogen from piggery manure anaerobic digestate slurry. Sci. Total Environ. 2015, 505, 102-112.

33. Chen, Y.C.; Lu, C. Kinetics, thermodynamics and regeneration of molybdenum adsorption in aqueous solutions with NaOCl-oxidized multiwalled carbon nanotubes. J. Ind. Eng. Chem. 2014, 20, 2517-2521. [CrossRef]

34. Zhang, M.; Gao, B.; Yao, Y.; Xue, Y.W.; Inyang, M. Synthesis of porous MgO-biochar nanocomposites for removal of phosphate and nitrate from aqueous solutions. Chem. Eng. J. 2012, 210, 26-32. [CrossRef]

35. Zhang, Z.R.; Yan, L.G.; Yu, H.Q.; Yan, T.; Li, X.G. Adsorption of phosphate from aqueous solution by vegetable biochar/layered double oxides: Fast removal and mechanistic studies. Bioresour. Technol. 2019, 284, 65-71. [CrossRef]

36. Yang, Q.; Wang, X.L.; Luo, W.; Sun, J.; Xu, Q.X.; Chen, F.; Zhao, J.W.; Wang, S.N.; Yao, F.B.; Wang, D.B.; et al. Effectiveness and mechanisms of phosphate adsorption on iron-modified biochars derived from waste activated sludge. Bioresour. Technol. 2018, 247, 537-544. [CrossRef]

37. Yin, Q.Q.; Ren, H.P.; Wang, R.K.; Zhao, Z.H. Evaluation of nitrate and phosphate adsorption on Al-modified biochar: Influence of Al content. Sci. Total Environ. 2018, 631, 895-903. [CrossRef]

38. Iida, T.; Amano, Y.; Machida, M.; Imazeki, F. Effect of surface property of activated carbon on adsorption of nitrate ion. Chem. Pharm. Bull. 2013, 61, 1173-1177. [CrossRef]

39. Wang, Z.H.; Guo, H.Y.; Shen, F.; Yang, G.; Zhang, Y.Z.; Zeng, Y.M.; Wang, L.L.; Xiao, H.; Deng, S.H. Biochar produced from oak sawdust by Lanthanum (La)-involved pyrolysis for adsorption of ammonium $\left(\mathrm{NH}_{4}{ }^{+}\right)$, nitrate $\left(\mathrm{NO}_{3}{ }^{-}\right)$, and phosphate $\left(\mathrm{PO}_{4}{ }^{3-}\right)$. Chemosphere 2015, 119, 646-653. [CrossRef]

40. Park, J.H.; Ok, Y.S.; Kim, S.H.; Cho, J.S.; Heo, J.S.; Delaune, R.D.; Seo, D.C. Evaluation of phosphorus adsorption capacity of sesame straw biochar on aqueous solution: Influence of activation methods and pyrolysis temperatures. Environ. Geochem. Health 2015, 37, 969-983. [CrossRef]

41. Ketcha, M.J.; Manga, N.H.; Daouda, K.; Tchoua, N.P.H. Kinetic and equilibrium studies of the adsorption of nitrates ions in aqueous solutions by activated carbons and zeolite. Res. J. Chem. Environ. 2007, 11, 47-51. 